\title{
Stage II Gallbladder Cancer AJCC v6
}

National Cancer Institute

\section{Source}

National Cancer Institute. Stage I/ Gallbladder Cancer AJCC v6. NCI Thesaurus. Code C5738.

Stage II includes: IIA: (T3, NO, M0); IIB: (T1, N0, MO); (T2, NO, MO); (T3, NO, MO). T2:

Tumor perforates the serosa (visceral peritoneum) and/or directly invades the liver and/or one other adjacent organ or structure, such as the stomach, duodenum, colon, or pancreas, omentum or extrahepatic bile ducts. (AJCC 6th ed.) - 2003 